
Journal

\title{
Electronic waste-a modern form of risk? On the consequences of the delay between the increasing generation of electronic waste and regulations to manage this increase
}

\author{
Jennie Olofsson \& Franc Mali
}

To cite this article: Jennie Olofsson \& Franc Mali (2017) Electronic waste-a modern form of risk? On the consequences of the delay between the increasing generation of electronic waste and regulations to manage this increase, Human and Ecological Risk Assessment: An International Journal, 23:6, 1272-1284, DOI: 10.1080/10807039.2017.1294478

To link to this article: https://doi.org/10.1080/10807039.2017.1294478

Accepted author version posted online: 16

May 2017.

Published online: 05 Jul 2017.

Submit your article to this journal

Џll Article views: 265

Q View related articles $\sqsubset$

View Crossmark data $[7$ 


\title{
Electronic waste-a modern form of risk? On the consequences of the delay between the increasing generation of electronic waste and regulations to manage this increase
}

\author{
Jennie Olofsson ${ }^{\mathrm{a}}$ and Franc Mali ${ }^{\mathrm{b}}$ \\ ${ }^{a}$ Department of Social Sciences, Mid Sweden University, Ostersund, Sweden; ${ }^{b}$ Faculty of Social Sciences, \\ University of Ljubljana, Ljubljana, Slovenia
}

\begin{abstract}
This article addresses the relation between the current proliferation of Information and Communication Technology (ICT) goods and services and the development of different kinds of risk assessments and policy documents. The ambition is to shed light on a, hithertho, lessdiscussed aspect of the development of risk assessments and policy documents, namely the time span between the development of new technologies and the development of regulatory frameworks. The concept of risk and danger can be seen as a potential means through which we can start to think about the consequences of the delay between the increased generation of electronic waste (e-waste) and the regulations to manage this increase. By using e-waste as a case study, this article provides the basis for a more general understanding of the relation between the development of new technologies and the development of regulatory frameworks. While it might be difficult to pin down the effects that this delay had/has for the subsequent development of ICTs, this article highlights the importance of taking into account not only how and by whom risk assessments and policy documents are developed, but also when they are developed in relation to the technologies that they serve to regulate.
\end{abstract}

\section{ARTICLE HISTORY}

Received 24 January 2017

Revised manuscript

accepted 6 February 2017

\section{KEYWORDS}

Information and

Communication Technology (ICT); risk assessment; policy making; electronic waste; risk

\section{Introduction and aim}

This article addresses the relation between the current proliferation of Information and Communication Technology (ICT) goods and services and the development of different kinds of risk assessments and policy documents. We shed light on a, hithertho, less-discussed aspect of the development of risk assessments and policy documents: the time span between the development of new technologies and the development of regulatory frameworks. In the case of ICTs, while computers have been a part of society since the mid-20th century, it is not until recently that risk assessments and policy documents regarding their material residues have been developed and put into force. This delay has been observed but not further explored. Wäger et al. (2005: 567) discussed the Precautionary Principle (PP) as a means to anticipate and minimize "potentially serious or irreversible risks under

CONTACT Jennie Olofsson jennie.olofsson@miun.se Department of Social Sciences, Mid Sweden University Campus Ostersund, Ostersund 83125 , Sweden.

๑) 2017 Taylor \& Francis Group, LLC 
conditions of uncertainty." The authors noted that while the PP has been incorporated into many international treaties for environmental protection, it "has rarely been applied to novel Information and Communication Technologies [...] and their potential environmental impacts." In a similar vein, Grossman (2006: 8) concluded that:

"Despite the enormous quantity of electronic waste generated, and the fact that we have been producing this trash at accelerating rates since the 1970s, regulations and systems for dealing with this refuse have only recently been developed and put to work.”

The above quotations show how, despite (or perhaps because of) the rapid pace of technological progression of ICT goods and service, regulatory measures were developed and put to work only recently. This means that the advancement of ICTs, at least for the first 25-30 years, proceeded pretty much without critical interventions of their effects. The promise of major, short-term benefits of high-tech devices such as computers, cell phones, tablets, and laptops might have occluded long-term dilemmas, such as the electronic waste (e-waste) generated by their proliferation as well as their environmental impacts. While the delay between the development of new technologies and the development of regulatory frameworks does not only concern ICTs, the increasing amount of its refuse makes the situation most alarming; more than 41 million tons of e-waste were produced worldwide in 2014 (Baldé et al. 2015). The delay between the increasing generation of e-waste and regulations to manage this increase differs from the regulations of other emerging technologies such as (green) biotechnology (genetically modified organisms [GMOs]), nanotechnology, and synthetic biology where regulations were/are developed in conjunction with, or even before the development of the technologies themselves.

This article highlights the importance of taking into account, not only how and by whom risk assessments and policy documents are developed-i.e., the procedural choices that preceed the development of risk assessments and policy documents (see, for comparison, Jasanoff (1995), Murphy et al. (2000), and Macfarlane (2003)) - but also when they are developed in relation to the technologies that they serve to regulate. In doing so, it employs the concepts of risk and danger (Beck 1992; Luhmann 1991; Giddens 1992), which can be seen as potential means through which we can start to think about the consequences of the delay between the increasing generation of e-waste and regulations to manage this increase. By using e-waste as a case study, this article provides the basis for a more general understanding of the relation between the development of new technologies and the development of regulatory frameworks. Ultimately, this article acknowledges the term entanglement (Hird et al. 2014) as a sufficient means through which the innate risks of technological progression of ICTs might be brought (back) into view.

\section{On ICTs and e-waste}

ICTs are habitually conveyed as immaterial services, shiny, sleek surfaces, the high-tech devices of today and the must-haves of tomorrow. At the same time, the continuous technological progression of ICTs, in terms of, for example pervasive computing, is contributing to increasing amounts of e-waste across the globe (see, for comparison, Köhler and Erdmann (2004)). Thinking of server halls, antennas, cables, and microchips (factors that are constitutive of today's seemingly immaterial and constantly connected society), we understand that what is habitually thought of as resource-free services in fact depend on huge material 
infrastructures in order to function. The discrepancy between high-tech devices and their material constituents becomes even more complicated as one considers the diminishing lifespans and the concurrent proliferation of ICTs, for example, in terms of smart devices, ubiquitous computing, and radio-frequency identification tags. Hence, technological progression of ICTs results not only in the construction of resource-intense infrastructures but also in an increasing amount of e-waste. Informed by the work of Mundada et al. (2004), our point of concern is that e-waste is intimately linked to, and an invisible effect of, the technological progression of ICTs. While we are living in one of the most exciting historical periods of scientific and technological development, featuring new converging technologies (info-, nano-, bio-, and cogno-sciences), this progression does not assure fulfillment of all human and social expectations [see, for comparison, Mali $(2004,2009)]$. On the contrary, it is clear that novel technologies serve a dual purpose as they both enhance life and bring about new risks (Wäger et al. 2005).

Considering the close link between the current consumption patterns of ICTs and the increasing amount of e-waste, what makes obsolete ICTs problematic is their status as hazardous waste at the same time as their image as resource-free, immaterial goods renders invisible the fact that e-waste is the fastest growing waste category in the world. Compared to, for example, household waste, e-waste is a complex waste category that includes computers, televisions, cell phones, and tablets, and also hair dryers, household appliances, vacuum cleaners, earphones, and batteries. Each product contains complex compounds of metals, elements, plastics, and other materials, something that requires diversified and adaptive recycling methods. While e-waste consists of contaminants such as lead, cadmium, mercury, beryllium, or brominated flame retardants, it holds both valuable and scarce metals, as well as reusable components that are in need of adequate treatment. This means that e-waste is at once hazardous, recyclable and reusable.

E-waste is also a changing waste category. As new and updated products are introduced, sold, and discarded at an increasingly rapid pace, current processes of recycling are in need of continuous adjustments and adaptations. This is to a large extent because different products use different compounds and material resources, something that in turn requires different kinds of recycling practices. Not only does this demonstrate a highly flexible e-waste recycling industry, it also shows that practices of recycling are part and parcel of current consumption patterns.

Recent transitions from one computer per household to multiple devices per user require enhanced e-waste management. Also, the miniaturization of electrical and electronic equipment has been followed by an increasing number of devices (Hilty 2005). This means that more, not less material is needed. In addition, the miniaturization of ICTs means that people are more likely to toss them into household waste. Ultimately, what actually constitutes ewaste is difficult to measure as e-waste is subjected both to gradual and geographically distributed processes of disassembly and international trade, which can be informal and illegal, as well as formal and institutionalized (see, for comparison, Lepawsky and McNabb (2010)).

\section{The waste electrical electronic equipment (WEEE) directive}

While developed and put to force relatively recently, e-waste management is today subjected to different and variable regulations and decrees, on national, European, and international levels. These regulations and decrees, however, are neither distributed and implemented, nor 
interpreted evenly across the globe. For example, the definitions and categories of hazardous wastes tend to differ among countries; material that would qualify as fuel in some countries has the status of waste in others. In addition, many developing countries, such as India and Indonesia, lack proper policy measures on how to manage e-waste (Panambunan-Ferse and Breiter 2013; Borthakur 2014; Heeks et al. 2015); at the same time, e-waste management is implemented in most industrialized countries (Panambunan-Ferse and Breiter 2013). The Basel Convention (http://www.basel.int/) came into force in 1989 and is currently ratified by 53 countries. Its fundamental aim is to promote environmentally sound management of hazardous wastes worldwide, mainly through restricting transboundary movements of hazardous waste and providing a regulatory system that applies to cases where transboundary movements are permissible.

The WEEE Directive came into effect among European Union (EU) members in 2003 www.ec.europa.eu/environment/waste/weee/index_en.htm). It mandates e-waste recycling in that it aims to prevent the emergence of e-waste, and increase reuse, recycling of material, and other types of recycling in order to decrease the disposal of e-waste. While the WEEE Directive concerns all the member states of the EU, implementation differs among nations. The Extended Producer Responsibility (EPR) is currently part of the WEEE Directive, and as such it holds producers of electrical and electronic products responsible "for the environmental impacts of their products" life-cycles [...]' (Sander et al. 2007: 1). While the implications of the producer responsibility might vary, they include financial obligations for managing e-waste, for example, in terms of collecting e-waste from households. Through the EPR, the WEEE Directive couples the producers of electrical and electronic equipment (EEE) to the waste that they produce, something that in turn highlights not only the link between ICTs and their material constituents, but also the production and consumption of ICTs and the e-waste recycling industry.

\section{Policies and directives-comparative cases}

After the aggressive spread of the use of GMOs across the globe during the 1990s, EU policy decision-makers (for example, the European Commission and the European Parliament) set up a precautionary framework, which requires that each GMO release is subjected to a prior evaluation of potential risks to human health as well as to the environment (Levidov 2009; Jasanoff 2007). This happened relatively early in the process of legislation. The reason that GMOs immediately became a sensitive risk policy issue in Europe has to do with the mad cow disease and the import of the first GMO food crops into Europe from the United States. At the time of these two concurring events, European citizens revolted against the lack of responses from the responsible policy authorities. This caused heated debates and triggered changes on the EU level, as well as on the level of EU-Member States (Fischer and Frewer 2007; Mali 2004). Policy decision-makers began to find suitable legislative frameworks to address the various kinds of risks associated with GMOs. On the EU level, stricter regulatory frameworks regarding the development and use of GMOs were adopted (European Commission 2003).

While these regulatory frameworks have evolved gradually since the 1990s-often in the form of a patchwork of specific regulations that interweaves with many vertical and horizontal EU policies-they have remained in line with the advances in (green) biotechnology over the last 25 years. Hence, EU policy regulations regarding (green) 
biotechnology currently cover a broad spectrum of topics, ranging from contained use of genetically modified micro-organisms to the release and marketing of products consisting of, or deriving from GMOs, for example, food, feed, and seeds. In this sense, the development of GMOs provides a good example of the co-existence of regulatory frameworks and the progression of emerging technologies. The EU labeling and the traceability of regulations concerning GMOs in the last 20 years can also be seen as an example of ex ante regulations of emerging technologies, something that does not seem to be the case when it comes the development of ICTs.

Another example of the concurrent development of emerging technologies and regulatory frameworks is nanotechnology. Similar to GMOs, nanotechnology was the center of attention at EU research and development (R\&D) policy bodies, in the mid-2000s. Early on, two strategic documents were published (European Commission 2004, 2005). In contrast to similar US policy documents (Roco and Brainbridge 2003), European R\&D policy documents did not insist on the primary development of nanotechnology as the basis for the improvement of human performance in the future. Instead, they pursued the idea of integrating the issue of safety risks in nanotechnology by shaping the future of European social wealthfare societies. As a consequence, these policy documents addressed the progress of nanotechnology (also) with regard to the risks that they posed for human health and the environment.

As a means to ensure more socially robust $R \& D$ governance frameworks, these policy documents also included ambitious goals to democratize regulatory R\&D policy mechanisms. As such, they supported initiatives that attempted to intervene at an early stage in the development of nanotechnology. Subsequent to the publication of these R\&D policy documents, different forms of voluntary self-regulations of nanotechnology emerged, as well as the use of what is referred to as the soft law. ${ }^{1}$ One example of the latter was the Code of Conduct that was produced by the Directorate General for Research of the European Commission (http://ec.europa.eu/research/science-society/document_library/pdf_06/nanocodeapr09_en.pdf). This Code of Conduct encouraged researchers in nanotechnology to, for example, limit exposure to nanomaterials and engage in dialoges with the lay public (European Commission 2008). The intent was to anticipate potential safety risks of nanomaterial and nanoparticles without constraining public regulations.

This and other Codes of Conduct allowed a constructive steering of new emerging technologies, at least within the member states of the EU. They enabled the establishment of a proactive scientific community, which identified and reported both risks and benefits to public authorities at an early stage. The Codes of Conduct are particularly useful when the risks of new emerging technologies (not limited to nanotechnology) are uncertain, and when there is an uncertain ground for legislative action (von Schomberg 2013).

The last, perhaps most illustrative case, is synthetic biology, a technology still in its infancy. Controversies around the very definition of synthetic biology have emerged (Frow 2015; Drew 2014): Does it represent a game changer in the context of biogenetic science or is it best understood in terms of what can be referred to as old wine in new bottles (in the sense of the continuation of traditional genetic engineering)? Notwithstanding, EU institutions are trying to provide control of the anticipated risks of synthetic biology using regulatory procedures. For example, three scientific committees of the European Commission

\footnotetext{
${ }^{1}$ The term soft law refers to a non-treaty law, where the rules of conduct, in principle, have no legally binding force, but that nevertheless may have practical effects (Tallacchini 2009).
} 
(2015) have prepared a common expert opinion on synthetic biology, focusing particularly on risk assessment methodologies and safety aspects. Prior to the development of synthetic biology, these committees also addressed potential hazardous and adverse effects that had to be submitted to stricter regulatory frameworks.

Policy decision-makers on the EU level work hard to establish ex ante, or at least concomitantly regulatory frameworks in order to optimally manage the complexity of emerging technologies. It is our assumption that the concurrent development of emerging technologies and regulatory frameworks is likely to foster an understanding of the consequences and uncertainities of these technologies as part and parcel of the technologies themselves. In the case of ICTs, however, regulatory frameworks have appeared only recently, something that leads us to believe that many consequences of ICT goods and services are seen as external to the technologies themselves. For example, as computers, cell phones, tablets, and laptops are habitually launched and sold in terms of resource-free, consumable goods, less is said about their status as hazardous waste (Olofsson 2015).

\section{Risk and danger}

An ample point of concern, from where we can understand the consequences that subsequent the current proliferation of ICTs, and how this is relevant for future development of policy documents and risk assessments, is to follow the distinction between the concepts of danger and risk. This distinction has been formulated in sociological theory and has become the main point of concern for almost every modern discussion of risk. Beck (1992) and Giddens (1990), for example, propose a distinction between danger, as recognized in traditional societies, and risk, as created by reflexive modernization. Risk is thus linked to modernization and the desire to control the future. This classification on danger and risk is important, because it indicates the nature and seriousness of scientific and technological risks. Beck (1992: 21) defines risk as a "systematic way of dealing with hazards and insecurities induced and introduced by modernization itself," as he notes that people in modern societies are subjected to risks that derive from their own creative powers, and materially transformed into hazardous sciences. Hence, risk is omnipresent, regardless of one's social and economic standing. For Beck (1992: 163), science is intimately linked to risk in that it is a source, both for identifying problems and finding solutions:

"Not only does the industrial utilization of scientific results create problems, science also pro-
vides the means-the categories and the cognitive equipment-required to recognize and pres-
ent the problems as problems at all, or just not to do so. Finally, science also provides the
prerequisites for 'overcoming' the threats for which it is responsible itself."

Science is thus a double-edged sword in that its industrial utilization is the cause of (sometimes, unpredictable) outcomes; at the same time, science also provides the means to frame (and overcome) these problems. Put differently, scientific measurements and subsequent knowledge production provide the means through which it is possible to identify and control risk (Hardy and Maguire 2016).

Luhmann (1991) adds a new dimension to the understanding of scientific and technological risks in that he takes into consideration the limited time and knowledge provided by modern societies to define and evaluate the risks that are introduced by unknown causes of new emerging sciences. Luhmann (1991) neither views risk as the contradiction of security, 
nor does he see risk as a synonym for insecurity, but rather as the way in which the future is contingent on present, current decisions. Similar to Beck (1992) and Giddens (1990), Luhmann (1991) understands risk as a conceptual part of any social system and as inherent in its decisions. ${ }^{2}$ He too draws a distinction between danger and risk, where danger is external to the system and risk is generated by the decisions of the system. Luhmann's (1986: 14, the authors' translation) conclusion is that "today's society threatens itself in an, until now, unknown respect." Informed by the work of Luhmann $(1986,1991)$, our assumption is that the key question of modern risk is not about the quantity of new dangers in the world (more or less severe, calculable or not), but rather how the future is conceptualized in, and contingent on the present, and how each decision, or abstention from a decision, concerning the future, determines risk. The definition of risk, then, cannot be seen as an objective measure of certain consequences, but as subjected to political struggles and processes of policy-making (Cranor 2004; Kuchinskaya 2012). Depending on the socio-political settings, the consequences of, for example, air pollution can be either obscured or the acceptable levels of exposure increased, something that in turn affects not only environmental standards, but also standards for human health.

\section{ICTs-a modern form of risk?}

Informed by the works of Beck (1992), Giddens (1990), and Luhmann (1991), we now turn toward additional studies on risk. The intention is to enhance the understanding of the concept of risk to also include the role that science plays in risk assessments and risk analyses, as well as the interlinkages between the understanding of risk and the understanding of contemporary society. Risk is, as noted above, neither an objective measure of a certain level of uncertainty, nor can it exclusively be referred to as a social construction. As Wynne (1992: 119) states:

"The knowledge used to define risk and justify ensuing regulations is confirmed only if the social world can indeed be reorganized and controlled to reflect the assumption built into that knowledge in the first place."

Inasmuch as we might be said to live in a risk society (Beck 1992), risk is also contingent upon the knowledge used to perceive it as "real." Wynne (1992) employs the terms intrinsic and situational risks (which together formulate the actual risks) to show the reciprocal character of risks. The term intrinsic risks correlates with the inherent properties of, for example, the chemicals composing waste while the term situational risks shows the ways in which people treat these risks. The latter is also defined by the kind of regulatory regimes of which it composes part. Wynne's (1992) distinction correlates with the fact that the definitions and categories of hazardous wastes tend to differ between countries; material that would qualify as fuel in some countries has the status of waste in others. Wynne's (1992) understanding of risk is further useful for the purposes of this article as it, similar to the works of Beck (1992), Giddens (1990), and Luhmann (1991), promotes an understanding of the built-in risks of technical processes and parameters.

\footnotetext{
2Luhmann treats risk, not as an object of "a first-order observation" ("Beobachtung erster Ordnung") (Luhmann 1991: 23) (which he terms "danger") but as a concept of "a second-order observation" ("Beobachtung zweiter Ordnung") (Luhmann 1991: 23).
} 
Risk analysis, then, is an integral part of, rather than something that is developed after, design and manufacture. Tracing the history of risk assessment as a scientifically disciplined way of analyzing risk and safety problems, Wynne (1992: 113) asserts that risk assessment was originally developed for relatively well-structured mechanical problems, and is equally critical of the term as today's problems "cannot be designed, manipulated, and reduced to within the boundaries of existing analytical knowledge." Put differently, the risk assessments that were previously used as a means to address well-structured mechanical problems are not relevant to problems that today most often involve global, and illstructured, systems.

Hardy and Maguire (2016) criticize scholars for augmenting the frontiers of risk discourse to concern basically all spheres of human life and by this dismissing alternative ways of understanding the world. They (2016: 103) propose the term "conditions of possibility" as a means to talk about, and act upon phenomena without reference to the concept of risk. Hardy and Maguire investigate the effects of what they refer to as a dominant risk discourse as both an instrument and an effect of power. In doing so, they distinguish among three different modes of organizing risk: Prospectively, in real time, and reterospectively. These three modes are all parts of the dominant risk discourse, which means that what counts as risk also follows a top-down protocol, where local (tacit) knowledge is omitted and/or trivialized in favor of expert knowledge.

Hardy and Maguire investigate the effects of the dominant risk discourse as both an instrument and an effect of power. In doing so, they (2016: 95) propose that even the resistance to this discourse can contribute to riskification, i.e., the "processes whereby risk becomes further entrenched as the natural way to talk about a variety of concerns." For example, recent attempts to involve representatives from the lay public in discussions concerning technological risks to human health might at first sight seem to resist the dominant risk discourse. At the same time, as these representatives are often referred to as citizen scientists, the scientific model that underpins the dominant risk discourse is sustained rather than challenged.

Science appears as the natural frame of reference (Wynne 2003: 404). Wynne emphasizes the term "civic epistemology" (2003: 402) as well as the term "midstream modulation" (2011: 791), as means through which representatives from the lay public can be involved in the processes of policy-making without necessarily running the risk of reproducing the dominant risk discourse. Midstream modulation can be seen as a form of public engagement with science, a collaboration that benefits from the strategic applications of the insights acquired from the field of S\&TS studies over the past 20 years. The advantages with enrolling representatives from the lay public are clear, not least when it comes to climate change, in particular as scientific uncertainties appear to undermine the authority of scientific knowledge (Wynne 2002; Shackley and Wynne 1996).

We acknowledge risk as an adequate means to explain the consequences and uncertainties of discarded ICT goods and services, precisely because it points toward the entire design and manufacturing process. E-waste admittedly comprises a modern form of risk in that it is an integrated part, rather than an external part of modern societies, and more importantly, of current ICT products and services. This means, for example, that toxicity (in terms of substances such as beryllium, lead, mercury, and flame-retardant substances) does not emerge when ICT products and services turn into e-waste. Rather, while actualized and subjected to different kinds of measures almost exclusively in conjunction with e-waste management, toxicity is (and needs to be acknowledged as) potentially present in any ICT product and service. 
While "the adverse consequences of technology" (Felt and Wynne 2007: 13) do not seem to concern the technological progression of ICTs, it is still fair to assume that many of its potentially grave consequences are unknown to us today, and consequently difficult to exactly estimate. This means that many of the risks that emerge as a consequence due to the increasing amount of e-waste cannot beforehand be technically comprehended and managed at the same time as it might be too late to act reactively.

Similar to other emerging technologies, the technological progression of ICTs has both cross-national and long-term effects. Not only are these effects becoming more complex and less easily codified, but also increasingly global in their character as they tend to move beyond and across national borders. As stated by Beck (2000: 218), "the new types of risks are simultaneously local and global, or 'glocal'." Specifically in relation to the technological progression of ICTs, we encounter these kinds of global, yet unevenly distributed, risks, for example, through illegal export of e-waste to countries such as Ghana, China, and India, countries that also lack strict legislations when it comes to e-waste. Another example of how local and global risks are amalgamated is the toxins that are released into the air and groundwater as old computers, cell phones, and tablets are disassembled and/or incinerated. While these leakages often occur subsequent to the use of rudimentary methods (burning circuit boards over open fire, for example), and are also dangerous to human health, landfilling of e-waste in developed countries has similar effects as it not only has the potential to contaminate soil and groundwater through leaching but also the air through toxic air emissions (Mundada et al. 2004). The rapidly increasing flow of e-waste, then, poses emerging-and global-risks for our society (Hilty 2005). These are actual risks (remember the distinction between intrinsic and situational risks), to the environment, as well as to human health; at the same time, the actuality of these risks and the extent of their effects does not mean that these risks are defined once and for all, nor does it mean that we have exhausted all the possible effects. This leaves us with risks that are at the same time actual and potential, distant, and close. In such situations, we are faced with 'dread' risk, which, following the typology of different types of risks by Schettler and Raffensperger (2004), ${ }^{3}$ involves a risk to the whole ecosystem.

In addition, and as also noted above, the very definitions of risks are subjected to political struggles, something that renders them more or less harmful depending on the socio-political context. Beck (1992: 184) notes, for example, that just because technological innovations increase the individual and collective wellbeing, "their negative effects (deskilling, risks of unemployment or transfer, threats to health, and natural destruction) have always found justification in the rises of the standard of living." Beck's annotation is specifically relevant in relation to the purposes of this article. Technological progression of ICTs is most often conveyed in terms of updated systems, enhanced software, increased screen resolution, bigger memory, etc. These improvements serve to, if not render invisible, at least legitimize the risks that follow as they allow for any potential negative effect to be treated separately and

\footnotetext{
${ }^{3}$ Depending on their disciplinary background, experts from diverse academic fields define scientific uncertainty differently (Landström et al. 2015). According to Schettler and Raffensperger's (2004) typology of uncertainties, the "model uncertainty" is inherent in technologies with multiple variables interacting in complex ways; "statistical uncertainty" occurs as a result of not knowing the value of a specific variable at a point in time or space, but being able to determine the probability distribution of the variable; and, "fundamental uncertainty" which extends the degree of indeterminacy into ignorance. In the case of the last uncertainty, people do not even know what they do not know (Schettler and Raffensperger 2004: 68).
} 
retrospectively at the same time as they "never call the socially evident value of the technological development itself into question” (Beck 1992: 202).

\section{"Entanglement" as a means to bring the risks of ICTs into view}

Hird et al. (2014) discuss practices of waste management in Canada; how these practices most often formulate part of everyday routines and, as a consequence, are rendered invisibly as a political issue. It is only when waste leaks, and when waste management systems fail or when the risks are too close to neglect that waste is brought into view, thus made public. To construct waste management as an issue, the authors note, requires work, something that involves human as well as non-human actors. Today's management of e-waste is most often pursued "in ways that do not disturb circuits of mass production and mass consumption" (Hird et al. 2014: 444). This serves to reinforce the distance between consumption of ICTs, formulation of policy documents and regulations, and the management of their material residues. This is because processes of consumption, discarding, and disassembling/recycling/reusing ICTs affect different groups of people, living in different parts of the world. Hence, while the risks posed by the technological progression of ICTs are at once local and global, actual and potential, and distant and close, they seem to remain a non-issue, at least for people living in the Western parts of the world, who are often led to believe that humans can compensate for these risks precisely through consumption and technological advancements, the same phenomena that we would argue also serve to sustain current ways of living.

We mentioned the works of Wynne (1992) and Hardy and Maguire (2016), and in particular their sceptisicm toward the term risk. However, we still maintain that the perception of risk has not been adequately elaborated in relation to the technological progression of ICT goods and services. It is true that " $[\mathrm{N}]$ ot all hazards are amenable to [the] quantification and prediction" that are characteristic to the dominant risk discourse (Hardy and Maguire 2016: 87). It is also true that the needs for security requirements are increasing as many of today's problems involve global and illstructured systems, something that in turn might intensify feelings of insecurity. At the same time, some kind of social "taboo" still seems to influence the risk perception of the technological progression of ICTs, at least in Europe, Canada, and the United States. This is evident as many of the measures that are currently taken to manage e-waste are system-preserving rather than system-challenging. At the same time as we are encouraged to recycle obsolete computers, cell phones, tablets, and laptops, current consumption patterns of ICT goods and services seem to be exempt from further scrutiny. These system-preserving measures might be one of the consequences for the delay between the development of ICT goods and services and the development of regulatory frameworks. As we are presented with external dangers rather than risks that are inherent in the system itself, the question of e-waste remains seemingly unremarkable, simply because of its disconnection with ICTs as consumer goods and resource-free services. It is clear that current consumption patterns, as well as the material constituents of ICTs "require work to become political issues" (Hird et al. 2014: 442). Hird et al. (2014: 457) use the term entanglement to show how public engagement can render waste into an issue by "entangling physical-technical processes ... with social processes of risk definition and democracy."

Highlighting entanglement, not only between the technological progression of ICTs and its material residues, but also between current consumption patterns of ICTs, subsequent practices 
of disposal (e.g., contamination of soil and groundwater, and adverse effects to human health) and global trade can serve to render visible, and make political, the potential risks posed by the technological progression of ICTs before they occur, and also incorporate local conditions and local knowledge into policy-making and risk assessments. While classical top-down perspectives assumed that the lay public, by necessity, had cognitive deficits in relation to risk assessment (something that in turn explained why democratization of science was not possible), the kind of public engagement described by Hird et al. (2014) is imagined not only as globally networked, but locally established in and through the activities of people, both experts and non-experts.

\section{Conclusion}

This article has proposed the concept of risk as an adequate point of concern in acknowledging the consequences and uncertainties of discarded ICT goods and services. The main idea has been to brace against the distinction between danger, as recognized in traditional societies, and risk, as created by technological progress in modern societies, to investigate some of the consequences of the delay between the increasing generation of e-waste and regulations to manage this increase. This means taking seriously the consequences and uncertainties as innate to the technologies themselves. Ultimately, this article investigated the term entanglement as a sufficient means through which the innate risks of technological progression of ICTs might be brought (back) into view. As ICT goods and services are habitually launched and sold in terms of resource-free, consumable goods, the consequences and uncertainties of their proliferation are seen as external to the technologies themselves, whereupon they are also rendered invisible as a political issue, and by this, also "deleted from collective attention" (Wynne 2003: 405). We suggest that this might partly be due to the delay between the increasing generation of e-waste and regulations to govern this increase. While it might be difficult to pin down the effects of the time span between the development of ICT goods and services and the development of regulatory frameworks, we have argued for the importance of taking into account, not only how and by whom risk assessments and policy documents are developed, but also when they are developed in relation to the technologies that they serve to regulate.

Acknowledging the uncertainties that unfold as a consequence of the technological progression of ICTs in terms of risks rather than dangers is of course not solely the act of policies and decrees, but requires a multitude of diverse and distributed actions. Hence, any formulation of policy documents and risk assessments with regard to the risks posed by ICTs should do more than just respond to individuals' waste needs. Put differently, as the use of raw material is directly connected to the amount of trash that is generated, any risk assessment or policy document that covers ICTs needs to take the connection between ICTs as consumer goods and their material residues seriously, and particularly as e-waste is intimately linked to, and an inevitable effect of, technological progression of ICTs. To conclude, ICT goods and services possesses an integrated and impending - however unevenly distributed - risk for the entire world at the same time as this risk seems to remain a non-issue, at least for people living in the Western parts of the world.

\section{References}

Baldé CP, Wang F, Kuehr R, and Huisman J. 2015. The global e-waste monitor - 2014. Bonn: United Nations University, IAS - SCYCLE 
Beck U. 1992. Risk Society: Towards a new modernity. London, Nebury Park and New Delhi: Sage Publications

Beck U. 2000. Risk society revisited: theory, politics and research programmes. In: Adam B, Beck U, and Van Loon J (eds), The Risk Society and Beyond, pp. 211-229. Sage, London

Borthakur A. 2014. Generation and management of electronic waste in the city of Pune, India. Bull Sci Technol Soc 34:43-52

Cranor CF. 2004. Toward understanding aspects of the Precautionary Principle. J Med Philos 29:259279

Drew E. 2014. Introduction. How would you design nature? In: Endy D, Daisy Ginsberg A, Calvert J, Schyfter P and Elfick A (eds), Synthetic Aesthetics. Investigating Synthetic Biology's Designs on Nature. The MIT Press, Cambridge and London

European Commission. 2003. Regulation concerning the traceability and labelling of genetically modified organisms and the traceability of food and feed products produced from genetically modified organisms and amending Directive 2001/18/EC. Available. http://eur-lex.europa.eu/legal-content/ EN/TXT/?uri = celex:32003R1830 (retrieved June 1, 2016)

European Commission. 2004. Towards a European Strategy of Nanotechnology. Luxembourg: Office for Official Publications of the European Communities, 2004. Available at: https://cordis.europa. eu/pub/nanotechnology/docs/nano_com_en_new.pdf (retrieved May 19, 2016)

European Commission. 2005. Nanosciences and nanotechnologies: An action plan for Europe. Office for Official Publications of the European Communities. Available at: https://ec.europa.eu/research/ industrial_technologies/pdf/policy/action_plan_brochure_en.pdf (retrieved May 19, 2016)

European Commission. 2008. Commission recommendation on a Code of conduct for responsible nanosciences and nanotechnologies research. Bruxellss, C (2008) 424, final. Available at: http://ec. europa.eu/research/science-society/document_library/pdf_06/nanocode-apr09_en.pdf (retrieved May 18, 2016)

European Commission. 2015. Opinion on Synthetic Biology II. Risk assessment methodologies and safety aspects. The SCENIHR at their plenary on 29 April 2015, the SCHER and the SCCS by written procedure on 4 May 2015. European Union, 2015)

Felt U and Wynne B. 2007. Taking European knowledge society seriously. Report of the expert group on science and governance to the science, economy and society directorate, directorate-general for research, European commission. Directorate-General for Research. Science, Economy and Society

Fischer A and Frewer L. 2007. Public acceptance of new technologies in food products and production. In: Flynn R and Bellaby P (eds), Risk and the Public Acceptance of New Technologies, pp. 66-85. Palgrave MacMillan, Hampshire and New York

Frow E. 2015. Rethorics and practices of democratization in synthetic biology. In: Wienroth $M$ and Rodrigues E (eds), Knowing New Biotechnology. Social Aspects of Technology Convergence. Routledge, London and New York

Giddens A. 1990. The Consequences of Modernity. Polity Press, Cambridge

Grossman E. 2006. High-Tech Trash: Digital Devices, Hidden Toxics, and Human Health. Island Press/Shearwater Books, Washington, Covelo and London

Hardy and Maguire. 2016. Organizing risk: Discourse, power, and "Riskification." Acad Manage Rev 41:80-108

Heeks R, Submanian L, and Jones C. 2015. Understanding e-waste management in developing countries: Strategies, determinants and policy implications in the Indian ICT sector. Inf Technol Dev 21:653-667

Hilty LM. 2005. Editorial. Electronic waste-an emerging risk?. Environ Impact Assess Rev 25:431435

Hird M, Lougheed S, Rowe KR, and Kuyvenhoven, C. 2014. Making waste management public (or falling back to sleep). Soc Stud Sci 44:441-465

Jasanoff S. 1995. Procedural choices in regulatory science. Technol Soc 17:279-293

Jasanoff S. 2007. Designs on Nature. Science and Democracy in Europe and The United States. Princeton University, Princeton, NJ

Kuchinskaya O. 2012. Twice invisible: Formal representations of radiation danger. Soc Stud Sci 43:78-96 
Köhler A and Erdmann 1. 2004. Expected environmental impacts of pervasive computing. Hum Ecol Risk Assess 10:831-852

Landström C, Hauxwell-Baldwin R, Lorenzoni I, and Rogers-Hayden T. 2015. The (mis)understanding of scientific uncertainty? How experts view policy-makers, the media and publics. Sci Cult 24:276-298

Lepawsky J and McNabb C. 2010. Mapping international flows of electronic waste. Can Geogr 54:177195

Levidow, L. 2009. Making Europe unsafe for agbiotech. In: Atkinson P, Glasner, P and Lock M (eds), Handbook of Genetics and Society. Mapping the New Genomic Era, pp. 110-126. Routledge, London and New York

Luhmann N. 1986. Oekologische Kommunikation. Westdeutscher Verlag, Opladen

Luhmann N. 1991. Soziologie des Risikos. Walter de Gruyter \& Co., Berlin and New York

Macfarlane A. 2003. Underlying Yucca Mountain: The interplay of geology and policy in nuclear waste disposal. Soc Stud Sci 33:783-807

Mali F. 2004. Recent dilemmas in the social and legal regulation of biotechnology in the European Union. Vest J Sci Technol Stud 17:39-60

Mali F. 2009. Bringing converging technologies closer to civil society: The role of the precautionary principle. Innovation -Eur J Soc Sci Res 22:53-75

Mundada MN, Kumar S, and Shedkar AV. 2004. E-waste: A new challenge for waste management in India. Int J Environ Stud 61:265-279

Murphy J, Levidow L, and Carr S. 2000. Regulatory standards for environmental risks: Understanding the US-European Union conflict over genetically modified crops. Soc Stud Sci 36:133-160

Olofsson J. 2015. "Are you fed up with your PC? Get a Mac." Swedish popular media representations of digital technologies and the stockpiling behavior of consumers. Stud Media Commun 3:11-21

Panambunan-Ferse M and Breiter A. 2013. Assessing the side-effects of ICT development: E-waste production and management. A case study about cell phone end-of-life in Manado, Indonesia. Technol Soc 35:223-231

Roco MC and Bainbridge WS (eds). 2003. Converging Technologiesfor Improving Human Performance: Nanotechnology, Biotechnology, Information Technology and Cognitive Science. Kluwer Academic Publisher, Dordrecht

Sander K, Schilling S, Tojo N, van Rossem C, Vernon J, and George C. 2007. The Producer Responsibility Principle of the WEEE Directive. Hamburg: Germany: DG ENV. Study Contract No. 07010401/2006/449269/MAR/G4

Schettler T and Raffensperger C. 2004. Why is a precautionary approach needed? In: Martuzzi M and Tickner M (eds), The Precautionary Principle: Protecting Public Health, the Environment and the Future of Our Children. WHO Regional Office of Europé, Copenhagen

Shackley S and Wynne B. 1996. Representing uncertainty in global climate change science and policy: Boundary-ordering devices and authority. Sci Technol Hum Values 21:275-302

Tallacchini M. 2009. Governing by values. EU ethics: Soft tool, hard effects. Minerva 47:281-306

von Schomberg R. 2013. A vision of responsible research and innovation. In: Owen R, Heintz M, and Bessant J (eds), Responsible Innovation. John Wiley, London

Wäger PA, Eugster M, Hilty LM, and Som C. 2005. Smart labels in municipal solid waste-a case for the precautionary principle? Environ Impact Assess Rev 25:567-586

Wynne B. 1992. Uncertainty and environmental learning. Reconceiving science and policy in the preventive paradigm. Global Environ Change 2:111-127

Wynne B. 2002. Risk and environment as legitimatory discources of technology: Reflexivity inside out? Curr Sociol 50:459-477

Wynne B. 2003. Seasick on the third wave? Subverting the hegemony of propositionalism. Response to Collins \& Evans (2002). Soc Stud Sci 33:401-417

Wynne B. 2011. Lab work goes social, and vice versa: Strategising public engagement processes. Sci Eng Ethics 17:791-800 